\title{
KECERDASAN EKOLOGIS DALAM BUKU SEKOLAH ELEKTRONIK MATA PELAJARAN BAHASA INDONESIA SMP
}

\author{
Sarwiji Suwandi, Ahmad Yunus, dan Laili Etika R. \\ FKIP Universitas Sebelas Maret Surakarta \\ e-mail: sarwijiswan@staff.uns.ac.id
}

\begin{abstract}
Abstrak
Penelitian ini bertujuan menjelaskan muatan kecerdasan ekologis dalam buku ajar sekolah elektronik (BSE) mata pelajaran Bahasa Indonesia SMP. Metode yang digunakan dalam penelitian ini adalah studi pustaka dan analisis isi. Muatan kecerdasan ekologis dalam BSE mata pelajaran Bahasa Indonesia meliputi: (1) mengidentifikasi komponenkomponen ekosistem; (2) memahami fungsi dan kegunaan komponen ekosistem; (3) memahami sistem pengelolaan alam dan lingkungan; (4) memahami tata nilai lingkungan, yang mencakup nilai kearifan lokal, nilai religius, dan nilai normatif; (5) menunjukkan keprihatinan atas kerusakan lingkungan atau pencemaran lingkungan; (6) melakukan adaptasi tingkah laku terhadap lingkungan; (7) memecahkan masalah yang timbul dari dampak lingkungan baik secara individual maupun kolektif; (8) mengelola/melestarikan sumber daya alam; dan (9) memanfaatkan lingkungan secara positif. Muatan nilai kecerdasan ekologis dalam BSE masih didominasi aspek pengetahuan dan belum menekankan aspek pemahaman, internalisasi nilai, dan penerapannya.
\end{abstract}

Kata kunci: kecerdasan ekologis, buku sekolah elektronik, Bahasa Indonesia

\section{ECOLOGICAL INTELLIGENCE \\ IN ELECTRONIC INDONESIAN LANGUAGE COURSE BOOKS FOR JHS STUDENTS}

\begin{abstract}
This study aims to explain ecological intelligence contents in electronic Indonesian language course books for junior high school (JHS) students. The methods in the study were literature review and content analysis. The ecological intelligence contents in the books include: (1) identifying ecosystem components; (2) comprehending the functions and uses of the components; (3) understanding environmental management systems; (4) understanding environmental values which comprise local wisdom and religious and normative values; (5) showing concern about environmental destruction and pollution; (6) adapting behavior to the environment; (7) solving problems arising from environmental impacts, either individually or collectively; (8) managing/preserving natural resources; and (9) exploiting the environment positively. The ecological intelligence contents are still dominated by the cognitive aspect and have not emphasized the comprehension, value internalization, and application aspects.
\end{abstract}

Keywords: ecological intelligence, electronic course books, Indonesian language

\section{PENDAHULUAN}

Bencana alam yang melanda Indonesia beberapa tahun belakangan ini telah menyebabkan kerugian yang begitu besar bagi masyarakat Indonesia, tidak saja secara material tetapi juga mental-spiri- 
tual. Badan Nasional Penanggulangan Bencana (BNPB) mencatat jumlah bencana alam tahun 2014 terjadi 372 kali dengan korban meninggal mencapai 245 jiwa, luka-luka 1.523 jiwa, dan korban mengungsi 1.044.990 jiwa. Jumlah tersebut didominasi oleh banjir, tanah longsor, kekeringan, dan kebakaran hutan (http:// www.republika.co.id).

Salah satu penyebab timbulnya berbagai bencana tersebut adalah ulah manusia sendiri. Pernyataan ini dapat dibuktikan melalui beberapa hasil penelitian tentang penyebab banjir. Banjir di kota-kota besar timbul akibat perubahan penggunaan lahan di sekitar daerah aliran sungai (DAS) (As-syakur, 2010:205) serta kebiasaan membuang sampah di sungai sehingga mengurangi kapasitas volume saluran air (Sartohadi dan Suryono, 2003: 199). Terjadinya pembalakan liar terhadap kekayaan hutan dengan berbagai latar belakang alasan sebagaimana dikemukakan oleh Kasia dkk. (2011: 1-2) turut pula berpengaruh terhadap keseimbangan alam.

Kenyataan di atas menunjukkan betapa buruknya kesadaran masyarakat tentang pentingnya menjaga lingkungan. Upaya-upaya penanggulangan bencana sebenarnya sudah banyak dilakukan, seperti penyusunan aplikasi SSOP Bantal untuk mendeteksi dini daerah rawan banjir dan tanah longsor (Santoso, 2012:53), peningkatan peran serta masyarakat dalam pengelolaan sampah (Riswan, dkk, 2011:31-38), revitalisasi fungsi DAS melalui pemberdayaan seluruh elemen masyarakat (Suganda, dkk, 2009:143-153). Namun, upaya-upaya tersebut tampaknya masih dilakukan secara parsial dan hanya menyentuh wilayah fisik dan teknis, sedangkan penanggulangan bencana dengan mengutamakan aspek mental berupa perubahan mindset dan penanaman sikap belum banyak dilakukan.

Penanaman sikap cinta terhadap lingkungan dapat diupayakan melalui jalur pendidikan. Buku merupakan faktor penting dalam pendidikan yang dapat memberikan pengetahuan, keterampilan, dan sikap positif kepada anak tentang pentingnya menjaga dan melestarikan lingkungan. Melalui buku pelajaran yang berbasis pada nilai-nilai cinta terhadap alam dan lingkungan sekitar, anak dituntun untuk memiliki kecerdasan ekologis (ecological intelligence), yakni menjadikan anak mampu menempatkan dirinya sebagai kontrol terhadap lingkungannya $(h u-$ man as in control of the natural environment) (Jung dalam Utina, 2012: 2). Kecerdasan ekologis ini diyakini memiliki kekuatan besar untuk menanggulangi berbagai bencana alam yang disebabkan oleh perilaku buruk manusia terhadap alam.

Upaya pelestarian lingkungan tersebut selayaknya menjadi perhatian semua elemen pendidikan. Pelestarian lingkungan tidak hanya menjadi tanggung jawab guru mata pelajaran IPA atau Sains, tetapi oleh semua guru mata pelajaran, termasuk guru Bahasa Indonesia. Buku atau bahan ajar Bahasa Indonesia yang tersedia belum memberikan perhatian yang cukup pada upaya menjaga dan melestarikan lingkungan (ekosistem). Untuk itu, dipandang penting melakukan penelitian untuk mendeskripsikan dan menjelaskan muatan kecerdasan ekologis dalam buku teks Bahasa Indonesia SMP. Dari data tersebut selanjutnya dapat dikembangkan/disusun model buku teks bahasa Indonesia berbasis kecerdasan ekologis.

Penanaman kesadaran tentang pelestarian lingkungan dapat dilakukan melalui pembelajaran bahasa. Melalui bahasa pengetahuan dan nilai-nilai dikomunikasikan dan diinternalisasikan. Wills (1996:12) dengan tegas menyatakan bahwa hal terpenting dalam mempelajari bahasa adalah menggunakan bahasa itu.

Keterampilan berbahasa yang terealisasikan dalam wujud penggunaan bahasa dapat dibedakan menjadi dua, yakni keterampilan reseptif dan produktif 
(Widdowson, 1987:36). Keterampilan reseptif adalah penggunaan bahasa untuk memahami pesan, pendapat, perasaan, dan sebagainya yang disampaikan orang lain. Keterampilan ekspresif adalah penggunaan bahasa untuk mengomunikasikan pesan, gagasan, pendapat, dan sebagainya kepada orang lain.

Pembelajaran merupakan sistem yang kompleks. Menurut Richards (2002:54), terdapat empat faktor utama dalam pembelajaran, yaitu sekolah, guru, proses pembelajaran, dan siswa. Buku pelajaran, menurut Cunningsworth (1995:7), hendaknya dipandang sebagai sebuah sumber dalam mencapai tujuan pembelajaran yang telah ditetapkan. Buku pelajaran memiliki peran ganda dalam pembelajaran bahasa dan dapat berfungsi sebagai (1) sumber untuk bahan presentasi lisan atau tertulis; (2) sumber aktivitas bagi praktik dan interaksi komunikatif siswa; (3) sumber referensi untuk siswa mengenai aspek kebahasaan (tata bahasa, kosakata, pengucapan, dll.); (4) sumber rangsangan dan ide bagi aktivitas bahasa kelas; (5) silabus (dalam buku terdapat tujuan belajar yang telah ditentukan).

Peran dan fungsi buku tersebut sejalan dengan pendapat Abbs dan Freebairn (dalam Cunningsworth, 1995: 97) tentang kebutuhan siswa dalam belajar bahasa. Terdapat lima kebutuhan siswa dalam mempelajari bahasa, yaitu (1) kebutuhan berkomunikasi secara efektif; (2) kebutuhan untuk mengenal sistem bahasa; (3) kebutuhan untuk menghadapi tantangan; (4) kebutuhan untuk lebih mendalami matapelajaran; dan (5) kebutuhan akan persilangan budaya.

Buku pelajaran dituntut memuat topik yang gayut dengan kebutuhan siswa. Jika tidak, buku akan kehilangan perhatian dari para penggunanya. Bahan pelajaran yang baik adalah bahan yang menciptakan respon yang asli, yang memberi informasi, menantang, membangkitkan semangat, menambah pengalaman, mendorong rasa ingin tahu, dan mengembangkan pendapat.

Buku pelajaran yang baik secara langsung maupun tidak juga mengomunikasikan nilai-nilai sosial dan budaya. Ini yang disebut 'kurikulum tersembunyi' yang berupa program mendidik, tetapi tidak dinyatakan dan tidak diperlihatkan. Hal ini bisa berupa ungkapan sikap dan nilai yang secara tidak sadar dilakukan tetapi tetap mempengaruhi isi dan kesan terhadap bahan pengajaran dan kurikulum secara keseluruhan. Karena sistem nilai yang pokok tidak eksplisit dan tidak dinyatakan, kita perlu melihat buku pelajaran tersebut secara teliti menemukan apa saja nilai-nilai yang tidak diungkapkan(Cunningsworth, 1995:91).

\section{METODE}

Pendekatan penelitian yang digunakan dalam penelitian ini adalah penelitian deskriptif kualitatif dengan metode analisis isi (content analysis). Analisis isi dilakukan untuk mendeskripsikan dan menjelaskan muatan kecerdasan ekologis dalam buku sekolah elektronik mata pelajaran Bahasa Indonesia untuk SMP. Selain analisis terhadap buku pelajaran, juga dilakukan studi pustaka yang berkaitan dengan kecerdasan ekologis.

Keabsahan data yang diperoleh dilakukan melalui triangulasi, pengecekan anggota, dan pemeriksaan sejawat melalui diskusi. Teknik analisis data yang digunakan adalah model analisis interaktif. Prosedur yang diguakan Miles dan Huberman (1984) adalah (1) pengumpulan data (focusing the collection data); (2) reduksi data (analysis during data collection, within site analysis, cross site analysis); (3) penyajian data (matrix displays some general suggestion); dan (4) penarikan simpulan (drawingand verivying conclutions). Analisis dilanjutkan dengan penarikan simpulan berdasarkan pada tema-tema yang menjadi fokus eksplorasi. 


\section{HASIL DAN PEMBAHASAN}

Manusia memiliki tanggung jawab dalam pengelolaan lingkungan. Menurut Soemarwoto (1991:73), pengelolaan lingkungan dapat diartikan sebagai usaha secara sadar untuk memelihara dan atau memperbaiki mutu lingkungan agar kebutuhan dasar kita dapat terpenuhi dengan sebaik-baiknya. Karena persepsi tentang kebutuhan dasar, terutama untuk kelangsungan hidup manusiawi, tidak sama untuk semua golongan masyarakat dan berubah-ubah dari waktu ke waktu, pengelolaan lingkungan haruslah bersifat lentur. Dengan kelenturan itu, kita berusaha untuk tidak menutup pilihan golongan masyarakat tertentu untuk mendapatkan kebutuhan dasarnya.

Untuk mendapatkan mutu lingkungan yang baik, usaha yang perlu dilakukan manusia adalah memperbesar manfaat lingkungan dan atau memperkecil risiko lingkungan. Untuk itu, manusia dituntut memahami krisis dan bencana lingkungan hidup serta memberi solusi. Menurut Keraf (2014: 124), solusi yang ditawarkan pada tempat pertama adalah pemikiran atau paradigma alternatif karena penyebab utama dari krisis dan bencana lingkungan hidup adalah kesalahan paradigma berpikir. Hanya dengan mengubah paradigma inilah akan muncul perilaku dan cara hidup baru sebagai solusi akhir bagi keseluruhan krisis dan bencana lingkungan hidup global.

Inti dari tawaran solusi ini adalah membangun sebuah masyarakat berkelanjutan, baik pada tingkat global, nasional, atapun daerah. Sebuah masyarakat berkelanjutan membangun dan menata kehidupannya secara bersama dengan bertumpu pada kesadaran tentang pentingnya lingkungan hidup. Kesadaran inilah yang disebut sebagai ecoliteracy atau melek ekologi (Capra, 1997:297).

Kesadaran yang sama, menurut Keraf (2014:125), dapat pula bertumpu pada filsafat bioregionalisme, yaitu kesadaran tentang pentingnya hidup selaras dengan alam dan sekaligus bertumpu pada mata rantai kehidupan dalam alam sekitar. Kesadaran tentang pentingnya alam inilah yang kemudian melahirkan dan menjelma dalam perilaku yang selalu ramah atas lingkungan hidup, perilaku yang selalu menjaga dan merawat lingkungan hidup sebagai sebuah kebiasaan dan pola laku hidup.

Upaya menjaga lingkungan menuntut manusia melek ekologi. Melek ekologi (ecolitary) adalah istilah yang digunakan oleh Capra untuk menggambarkan manusia yang sudah mencapai tingkat kesadaran tinggi tentang pentingnya lingkungan hidup. Istilah lain yang sering digunakan adalah ecological literacy.

Ecoliteracy mengacu pada makna orang yang sudah tercerahkan tentang pentingnya lingkungan hidup. Ecoliteracy menggambarkan kesadaran tentang pentingnya lingkungan hidup. Orang yang sudah sampai pada taraf ecoliteracy, dengan demikian, adalah orang yang sudah sangat menyadari betapa pentingnya lingkungan hidup, pentingnya menjaga dan merawat bumi, ekosistem, alam sebagai tempat tinggal dan berkembangnya kehidupan. Atas dasar dan digerakkan oleh kesadaran inilah manusia menata pola dan gaya hidupnya menjadi pola dan gaya hidup yang selaras dengan lingkungan hidup. Manusia lalu menggunakan kesadaran tersebut untuk menuntun hidupnya dalam segala dimensinya sampai menjadi sebuah budaya yang merasuki semua anggota masyarakat untuk akhirnya terciptalah sebuah masyarakat yang berkelanju$\tan$ (Keraf, 2014:127). Untuk itu, menurut Keraf (2014: 129), pentingnya merevitalisasi komunitas-komunitas - termasuk komunitas pendidikan, komunitas bisnis, dan komunitas politik-agar prinsipprinsip ekologi bisa diwujudnyatakan di dalam komunitas-komunitas sebagai prinsip-prinsip pendidikan, manajemen, dan politik. 
Prinsip-prinsip ekologis yang dimaksudkan oleh Capra (1997: 298-304) meliputi prinsip interdependensi, daur ulang, kemitraan, fleksibilitas, dan keragaman. Dengan sedikit merevisi prinsip-prinsip ekologis di atas dalam bukunya The Hidden Connections, Capra (2004: 201-202) merumuskan prinsip-prinsip itu sebagai jejaring (networks), siklus (cycles), energi surya (solar energy), kemitraan (pertnership), keanegaramaan (diversity), dan keseimbangan dinamis (dynamic balance).

Berkes dalam Pilgrim, et. al, (2008: 1004-1005) mendeskripsikan empat tingkatan dalam kecerdasan ekologis, yakni (1) mengidentifikasi komponen-komponen ekosistem, baik biotik maupun abiotik; (2) memahami fungsi dan kegunaan setiap komponen dalam ekosistem; (3) memahami sistem pengelolaan alam dan lingkungan; (4) memahami dan mampu menjalankan tata nilai yang berlaku dalam sistem ekologi.

Kecerdasan ekologis mengacu pada pemahaman akan dampak ekologis tersembunyi dan pemecahan untuk memperbaiki hal tersebut. Kecerdasan ekologis memadukan keterampilan kognitif dengan empati terhadap segala bentuk kehidupan. Kecerdasan sosial dan emosional terbangun atas kemampuan untuk melihat dari sudut pandang orang lain, merasakan apa yang dirasakan orang lain, dan menunjukkan kepedulian kita. Kecerdasan ekologis memperluas kapasistas tersebut ke seluruh sistem alami. Kita menunjukkan empati dan merasa sedih melihat tanda-tanda penderitaan bumi atau kita bertekad untuk membuat segalanya menjadi lebih baik. Empati yang meluas ini meningkatkan analisis rasional terhadap unsur penyebab dan memengaruhi motivasi untuk membantu. Kita harus mempelajari kepekaan baru terhadap serangkaian ancaman tak dikenal, yang berada di luar jangkauan radar sistem saraf dan mempelajari cara menghadapinya. Untuk itulah diperlukan kecerdasan ekologis (Goleman, 2009).

Pada beberapa persoalan, kecerdasan atau wawasan ekologis sering dikaitkan dengan nilai-nilai kearifan lokal kelompok masyarakat adat. Banyak pakar melihat bahwa wawasan dan kearifan ekologi yang dimiliki oleh masyarakat pedesaan memiliki peran penting dalam upaya pengelolaan sumber daya alam, pengayoman terhadap keanekaragaman hayati, dan memberikan model atau cara hidup dengan lingkungan (Turner, Ignace, and Ignace, 2000:1275).

Kearifan lokal dapat berwujud nyata (tangible) dan takberwujud (intangible), yaitu nilai-nilai yang turun-temurun dan masih dilaksanakan, di antaranya tercermin dalam tata wilayah (rumah adat, permukiman, pengairan, sawah dan ladang serta hutan), tata wayah yang ditunjukan berdasarkan fenomena alam, dan tata lampah yang diwujudkan dalam aturan-aturan berkenaan dengan lingkungan (etika lingkungan) serta upacara adat. Nilai-nilai tata lingkungan yang ada di antaranya nilai adaptif terhadap lingkungan, nilai preventif terhadap bencana, nilai keseimbangan dan keselarasan ekologis, nilai kesinambungan, nilai kepercayaan, nilai kemasyarakatan (sosial dan budaya).

Tata nilai sosial budaya dapat diartikan sebagai pola cara berpikir atau aturanaturan yang mempengaruhi tindakan-tindakan dan tingkah laku warga masyarakat dalam kehidupan sehari-hari. Pada cara berpikir itu tumbuh berkembang dan kokoh sebagai pedoman dalam bertingkah laku dalam masyarakat itu sendiri. Nilainilai sosial budaya yang telah mengakar dalam kehidupan masyarakat merupakan salah satu modal dasar bagi masyarakat untuk membangun dan melestarikan lingkungan.

Berdasarkan berbagai pendapat ahli di atas dapat disintesiskan bahwa kecerdasan ekologis adalah kemampuan manusia dalam berinteraksi dengan lingkungan

Kecerdasan Ekologis dalam Buku Sekolah Elektronik Mata Pelajaran Bahasa Indonesia SMP 
serta kemampuan beradaptasi, mengontrol, mengatur, mempeduli, menjaga, melestarikan, dan memanfaatkan lingkungannya demi kelangsungan hidup manusia. Komponen yang tercakup dalam kecerdasan ekologis meliputi (1) mengidentifikasi komponen-komponen ekosistem, baik abiotik maupun biotik; (2) memahami fungsi dan kegunaan komponen ekosistem, baik abiotok maupun biotik; (3) memahami sistem pengelolaan alam dan lingkungan, baik abiotik maupun biotik; (4) memahami tata nilai lingkungan, yang meliputi nilai kearifan lokal, nilai religius, dan nilai normatif; (5) menunjukkan keprihatinan atas kerusakan lingkungan atau pencemaran lingkungan, baik abiotik maupun biotik; (6) melakukan adaptasi tingkah laku terhadap lingkungan, baik abiotok maupun biotik; (7) memecahkan masalah yang timbul dari dampak lingkungan (abiotik maupun biotik), baik secara individual maupun kolektif; (8) mengelola/ melestarikan sumber daya alam (abiotik dan biotik), baik secara individual dan kolektif; dan (9) memanfaatkan lingkungan secara positif (abiotik dan biotik), baik secara individual maupun kolektif.

Berdasarkan konsep kecerdasan ekologis yang telah disintetis dari berbagai teori di atas, selanjutnya buku sekolah elektronik mata pelajaran Bahasa Indonesia SMP dianalisis dan dideskripsikan hasilnya berikut ini.

\section{Berbahasa dan Bersastra Indonesia} untuk SMP/MTs Kelas VIII Karangan Asep Yudha Wirajaya dan Sudarmawati

Buku pertama yang dianalisis adalah Berbahasa dan Bersastra Indonesia untuk SMP/MTs Kelas VIII karangan Asep Yudha Wirajaya dan Sudarmawati (selanjutnya disingkat BBI8 A\&S). Buku pelajaran ini diterbitkan oleh Pusat Perbukuan Depdiknas tahun 2008 dan memiliki ketebalan 208+viii halaman.
Terdapat tujuh komponen kecerdasan ekologis pada buku pelajaran tersebut, yakni mengidentifikasi komponen ekosistem, memahami fungsi dan kegunaan komponen ekosistem, memahami sistem pengelolaan lingkungan, memahami tata nilai lingkungan, menunjukkan sikap menghargai lingkungan serta keprihatinan atas kerusakan lingkungan atau pencemaran lingkungan, melakukan adaptasi tingkah laku terhadap lingkungan, memecahkan masalah yang timbul dari dampak lingkungan, mengelola/ melestarikan sumber lingkungan hidup, dan memanfaatkan lingkungan secara positif.

Tujuh dimensi kecerdasan ekologis yang dimuat pada buku tersebut masingmasing dideskripsikan dalam subdimensi terkait, yakni aspek abiotik dan biotik, serta kearifan lokal, nilai religius, dan nilai literer.Secara persentase, pemunculan komponen kecerdasan ekologis dalam buku pelajaran tersebut mencapai $77 \%$ karena dari sembilan komponen kecerdasan ekologis yang ada, dua komponen kecerdasan ekologis tidak terdapat dalam buku pelajaran tersebut. Sementara itu, jika dilihat dari aspek kecerdasan ekologis, buku pelajaran tersebut baru mencapai 40,63\% saja (13 dari 32 aspek yang dirumuskan).

Dimensi mengidentifikasi komponen ekosistem aspek abiotik tersaji pada bagian evaluasi Pelajaran 3. Di dalamnya ditemukan wacana yang membahas keindahan Pulau Karimunjawa, meliputi keindahan pantai, cahaya matahari pagi dan sore hari, serta kesejukan udara (BBI8 A\&S, 2008: 65). Sementara itu, pada wacana Pelajaran 9 dan 10 ditampilkan puisi "Masih Tersisa" karya Taufiq Abi Sabda berisi tentang keindahan alam Indonesia yang patut dibanggakan dan disyukuri keberadaannya dan puisi "Pada Gelombang” karya Tri Astoto Kodarie yang menggambarkan keindahan laut dengan ombak, batu karang, dan burung- 
burung beterbangan (BBI8 A\&S, 2008: 172 \& 185).

Komponen memahami fungsi dan kegunaan komponen ekosistem buku BBI8 A\&S hanya memuat aspek biotik, seperti tampak pada tugas Evaluasi Pelajaran 5. Di dalamnya dijelaskan fungsi dan manfaat hutan bakau. Petikan "Sejatinya, 1.300 hektar hutan bakau bermanfaat sebagai daerah resapan air serta penahan air untuk Jakarta" menunjukkan bukti manfaat yang dihasilkan dari hutan bakau. Materi tersebut memberikan pemahaman kepada siswa mengenai fungsi/kegunaan unsurunsur biotik (BBI8 A\&S, 2008: 100).

Muatan memahami sistem pengelolaan lingkungan (manusia, hewan, tumbuhan, dan mikroba dalam BBI8 A\&S ditampilkan dalam kaitan aspek abiotik, seperti tertuang dalam wacana berjudul "Pencemaran Lingkungan" yang memuat strategi penyelesaian masalah pencemaran, yang terdiri atas dua langkah, yaitu langkah pencegahan dan pengendalian (BBI8 A\&S, 2008: 91-92).

Komponen memahami tata nilai lingkungan dalam buku ini hanya diperjelas dengan muatan nilai normatif. Hal tersebut tampak pada petikan hasil wawancara pada wacana berjudul "Masalah Lingkungan, Kita Tinggal Tunggu Waktu" yang memaparkan UU No 4 Tahun 1982 tentang Pengelolaan Lingkungan Hidup dengan berbagai analisis kekurangan dan kelebihannya, serta wacana Pelajaran 10 yang menampilkan UU No. 23 Tahun 1997 tentang Pengelolaan Lingkungan Hidup sebagai penguat argumen penulis tentang perempuan dalam pengelolaan lingkungan hidup (BBI8 A\&S, 2008: $94 \& 184$ ).

Buku BBI8 A\&S memuat materi komponen menunjukkan sikap menghargai lingkungan serta keprihatinan atas kerusakan lingkungan atau pencemaran lingkungan melalui paparan aspek abiotik - sebagaimana tersaji dalam Pelajaran 7 (“... Misalnya kalian ingin menulis tentang laut, sejenak kalian bayangkan dan renungkan tentang laut. ..."), tugas Pelajaran 9 ("Selain perubahan iklim, emisi kendaraan bermotor dan industri yang dapat menimbulkan efek gas rumah kaca diperkirakan juga akan meningkatkan temperatur global rata-rata $14^{\circ} \mathrm{C}$ di akhir abad ini") yang memberikan gambaran tentang bahaya emisi kendaraan dan industri terhadap gejala pemanasan global, bahan diskusi dampak penggunaan teknologi yang dapat merusak lingkungan yang memungkinkan siswa memiliki keprihatinan terhadap penggunaan teknologi yang berdampak pada kerusakan lingkungan - serta aspek biotik seperti terlihat pada kutipan “... Limbah, polusi, dan kebisingan sepertinya merupakan satu kesatuan yang tidak mungkin lepas dari penggunaan mesin-mesin. ..." (BBI8 A\&S, 2008: 91, 108-109, 136, 163).

Materi bermuatan komponen memecahkan masalah yang timbul dari dampak lingkungan dalam buku ini hanya disinggung pada aspek abiotik. Contoh muatan tersebut tersaji pada Uji Kemampuan 2 Pelajaran 5 berupa tugas yang diberikan kepada siswa untuk melakukan wawancara dengan tema masalah lingkungan yang ada di sekitar guna memikirkan cara atau strategi untuk memecahkan masalah lingkungan (BBI8 A\&S, 2008: 95).

Sementara itu, komponen memanfaatkan lingkungan secara positif disajikan dalam dua aspek, abiotik dan biotik. Petikan wawancara dengan Bagas Kurniawan, pemilik Ninety Nine Trees Community Kampung Rusa berisi strategi memanfaatkan lingkungan secara positif sebagaimana terlihat pada kutipan berikut. "Caranya minimal kita punya rumah, kolam ikan, dan punya tanaman untuk diolah. Jadi kita berkebun. ... Dengan kita membuat makanan yang diambil dari alam, otomatis kehidupan kita secara ekonomi maupun sosial lainnya akan lebih baik." (BBI8 A\&S, 2008: 101).

Secara umum, buku BBI8 A\&S cukup banyak memuat komponen kecerdasan 
ekologis, sekalipun aspek kecerdasan ekologis masih kurang. Kekurangan yang terdapat dalam buku BBI8 A\&S meliputi: (1) dimensi kecerdasan ekologis lebih didominasi pada aspek kognitif dan afektif, sedangkan aspek psikomotor tidak banyak ditemukan, (2) belum ada kesinambungan antara wacana berbasis kecerdasan ekologis dengan tugas atau tagihan yang diberikan kepada siswa, (3) dimensi kecerdasan ekologis yang muncul dirasa masih kurang variatif, dan (4) buku belum mengarahkan siswa untuk memberdayakan dan melestarikan lingkungan, khususnya lingkungan sekitar.

Namun demikian, terlepas dari kekurangan yang ada, buku ini memiliki kelebihan, yakni (1) wacana tentang keindahan alam, sistem pengelolaan lingkungan, masalah pencemaran lingkungan, dan strategi memanfaatkan alam secara positif banyak dikandung dalam buku ini, serta (2) dimensi-dimensi kecerdasan ekologis tidak saja muncul pada tema lingkungan pada Pelajaran 5, tetapi secara merata dapat dijumpai pada hampir semua tema.

\section{Bahasa Indonesia (untuk SMP/MTs Kelas VII) Karya Atikah Anindyarini dan Sri Ningsih}

Buku kedua yang dianalisis berjudul Bahasa Indonesia (untuk SMP/MTs Kelas VII) (selanjutnya disingkat BI7 AA\&S) yang disusun oleh Atikah Anindyarini dan Sri Ningsih, diterbitkan oleh Pusat Perbukuan, Departemen Pendidikan Nasional pada tahun 2008 dan memiliki ketebalan $\mathrm{v}+154$ halaman.

Dimensi mengidentifikasi komponen ekosistem (abiotik dan biotik) ditampilkan pada Pelajaran 1 dan 10. Pelajaran menyajikan tema Menjaga Kelestarian Lingkungan. Pentingnya air (Pelajaran 1)disajikan baik pada pengantar pelajaran, cerita pengalaman yang mengesankan, teks bacaan, rubrik Rehat Sejenak, maupun bacaan soal pada Uji Kompetensi 1 (BI7 AA\&S, 2018: $1,5,6,7,8,12$, dan 13).
Unsur identifikasi ekosistem biotik lain yang dimuat dalam buku ini adalah udara, tanah, dan musim. Selain itu, terdapat juga unsur abiotik yang berupa unsur ekosistem waduk, pantai, dan laut. Teks yang berjudul Tamasya ke Masa Silam membahas cahaya matahari.

Materi yang bermuatan identifikasi unsur ekosistem biotik banyak ditemukan pada Pelajaran 8 yang bertema Peningkatan Hasil Pertanian dan Pelajaran 10 yang bertema Menjaga Kelestarian Alam. Unsur biotik yang terdapat pada buku ini adalah tumbuhan. Terdapat pula sebuah teks hasil wawancara yang membahas cabai kathur serta keunggulannya.

Aspek biotik lainnya adalah hewan. Pada Pelajaran 1 terdapat sebuah teks pengalaman yang mengesankan yang membahas pencegahan demam berdarah. Dalam teks tersebut dibahas tentang nyamuk. Dalam soal Uji Kompetensi 1 terdapat unsur biotik kerang. Bagian Rubrik Rehat Sejenak Pelajaran 8 membahas unsur biotik hewan, yakni wereng dan kumbang lembing. Pada Pelajaran 10 terdapat sebuah teks laporan hasil wawancara mengenai pelestarian penyu di Sulawesi Utara, teks bacaan yang berjudul Keindahan Alam Bawah Laut membahas secara detail mengenai penyu laut dan berbagai macam ikan hias (BI7 AA\&S, 2008: 132 ).

Buku BI7 AA\&S juga memuat materi dimensi memahami fungsi dan kegunaan komponen ekosistem. Subdimensi abiotik ditampilkan dalam bentuk ulasan mengenai kegunaan air bersih secara implisit. “... saluran air agar tetap mengalir lancar. ... Hidup sehat diawali dari lingkungan yang sehat". Apabila air mengalir lancar, pertumbuhan nyamuk penyebab demam berdarah tidak berkembang, maka masyarakat terhindar dari penyakit demam berdarah (BI7 AA\&S, 2008: 5 dan 7).

Muatan materi memahami sistem pengelolaan lingkungan dalam buku ini dimunculkan pada beberapa bagian 
untuk aspek abiotik dan biotik, seperti terlihat pada Rubrik Rehat Sejenak Pelajaran 1 yang membahas cara pengolahan sampah kering (anorganik), “... tempat sampah sebaiknya yang tertutup ...." dan teks soal nomor 9 Uji Kompetensi 1 yang membahas mengenai pengolahan air limbah yang harus sesuai dengan ketentuan baku mutu limbah cair, "...pengolahan limbar cair perusahaan tersebut tidak melebihi ketentuan baku mutu limbah cair", serta penyampaian amanat kepada anak dilakukan dengan memaparkan kondisi memprihatinkan ulah manusia yang demi keuntungan komersial justru melalaikan kelestarian lingkungan (BI7 AA\&S, 2008: 11 \& 12).

Materi lain yang memuat aspek abiotik adalah Rubrik Rehat Sejenak Pelajaran 1 yang membahas cara pengolahan sampah basah (organik) ("...pisahkan antara sampah kering dan sampah basah.") dan Uji Kompetensi Semester 2, yaitu teks yang berjudul Pontianak Kembangkan Lidah Buaya di Lahan Gambut. Melalui bacaan ini, anak akan memahami bahwa tanah gambut apabila diolah dengan benar ternyata dapat dimanfaatkan untuk budidaya lidah buaya (BI7, 2008: 147).

Sementara itu, aspek biotik ditampilkan melalui materi soal esai Uji Kompetensi 1 berupa teks yang berjudul Hutan Konservasi Dirambah yang membahas mengenai penebangan liar di Taman Wisata Alam (TWA) Asuansang (BI7, 2008:11). Selain itu, terdapat sebuah hasil wawancara pada uji Kompetensi 8 yang membahas efisiensi pengolahan sayuran aeroponik ("Pemasaran sayuran aeroponik mudah ...") dan teks pada Uji Kompetensi Semester 2 berjudul Pontianak Kembangkan Lidah Buaya di Lahan Gambut yang menjelaskan bahwa lidah buaya dapat diolah menjadi minuman, shampo, jus, dodol, dan makanan (BI7 AA\&S, 2008: $115 \& 147)$.

Untuk komponen memahami tata nilai lingkungan, buku ini menampilkan materi bermuatan subdimensi nilai kearifan lokal, normatif, religius, dan literer.
Paparan tentang kebiasaan warga Desa Lalumpe yang gemar menyelamatkan penyu di Pantai Tulaun dengan cara melaporkan pencuri penyu kepada kepala desanya ("... setiap kali ada yang menangkap penyu, penduduk melaporkan kepada saya.") dan bantuan dari World Wide Life Fund (WWF) berupa uang segar, kakus umum, dan instalasi air bersih untuk warga yang terbukti tidak menangkap penyu pada Pelajaran 10 mengungkapkan aspek nilai kearifan lokal (BI7 AA\&S, 2008: 137).

Nilai literer dan religius dikemukakan pada Pelajaran 1 melalui dongeng Si Janda dan Ketela Pohon yang memberi pemahaman kepada anak bahwa kehidupan di bawah kendali kuasa Tuhan (BI7 AA\&S, 2008: 3). Hal tersebut dilengkapi dengan muatan subdimensi nilai normatif melalui sajian teks berjudul Keindahan Alam Bawah Laut yang di dalamnya terdapat penjelasan hukum adat yang berlaku di Bali (“... kami nelayan bebas sianida! Jika ada yang melanggar, hukum adat berbicara dan sanksinya bisa berupa pengucilan oleh seluruh warga desa" (BI7 AA\&S, 2008: 137).

Nilai-nilai literer dalam buku ini diwakili oleh dongeng (legenda) yang berjudul Si Janda dan Ketela Pohon, cerita anak yang berjudul Kebaikan Berbuah Kebaikan, teks bacaan pada soal Uji Kompetensi yang berjudul Marty, Saat Pak Jago Sakit, Asal Usul Nama Madura, puisi Pamanpaman Tani Utun karya Piek Ardiyanto Supriyadi, cerpen Tamasya ke Masa Silam, dan puisi berjudul Serenade Pagi: Dusun Nenekku dalam Kerinduan. (BI7 AA\&S, 2008: 44-45, 58, 75, 113, 134, dan 138)

Buku ini juga memuat materi yang menunjukkan sikap menghargai lingkungan serta keprihatinan terhadap kerusakan lingkungan seperti tampak pada Pengantar Pelajaran 1 penulis memaparkan kondisi lingkungan yang sudah mengkhawatirkan karena tercemar dan mengajak siswa untuk peduli dan menjaga kelestarian lingkungan, "... jika seluruh masyarakat peduli dan ikut menjaga serta 
melestarikannya, kerusakan lingkungan pasti dapat dicegah". Pada bagian lain, teks pengalaman pribadi yang membahas demam berdarah juga mengajak siswa untuk turut menjaga kebersihan lingkungan sekitar dengan bekerja bakti, "... akhirnya, mereka bekerja bakti membersihkan lingkungan sekitar, menguras bak mandi, ...." (BI7 AA\&S, 2008: 1\& 5).

Unsur kecerdasan ekologis pada komponen melakukan adaptasi tingkah laku terhadap lingkungan abiotik dan biotik secara singkat disinggung melalui teks yang berjudul Keindahan Alam Bawah Laut. Di dalam teks tersebut dijelaskan bahwa di Bali terdapat kesepakatan para nelayan untuk tidak menggunakan sianida saat mencari ikan di laut, yang melanggar kesepakatan akan mendapatkan sanksi. Oleh karena itu, siswa didorong untuk tidak melanggar larangan tersebut saat berada di Bali demi menjaga laut yang sehat (BI7 AA\&S, 2008: 137)

Penyajian komponen memecahkan masalah yang timbul dari dampak lingkungan disajikan dalam Rubrik Rehat Sejenak. Siswa diajak untuk turut ambil bagian menjaga kebersihan lingkungan. Siswa harus memiliki kesadaran pribadi untuk memisahkan sampah anorganik dan organik. Sampah yang berupa kertas bekas, kantong plastik, botol, dan kaleng bekas dijadikan satu pada tempat sampah anorganik (BI7 AA7S, 2008: 11).

Buku ini juga memuat komponen melestarikan sumber lingkungan hidup. Dalam teks yang berjudul Keindahan Alam Bawah Laut siswa diberi pemahaman bahwa cita-cita masyarakat mengenai kelestarian lingkungan (kelestarian air) dapat diupayakan dengan penyusunan hukum yang jelas. Hukum tersebut selanjutnya dipublikasikan dan dengan sanksi yang mengikat niscaya masyarakat jera mengulangi perbuatan yang merugikan lingkungan (BI7 AA\&S, 2008: 137).

Berdasarkan sembilan komponen kecerdasan ekologis yang dirumuskan, semua sudah tersaji dalam buku ini. Di dalamnya, terdapat muatan 21 aspek dari 32 aspek kecerdasan ekologis yang dirumuskan. Dengan kata lain, buku tersebut memuat $100 \%$ dimensi kecerdasan ekologis dan $65,63 \%$ untuk subdimensi kecerdasan ekologis.

Dapat dikemukakan bahwa kelebihan buku ini adalah (1) materi, tugas, dan latihan soal sudah sesuai dengan kompetensi dasar yang akan dipelajari oleh siswa dan (2) setiap bagian pelajaran dalam buku ini sudah diberi materi pengantar pembelajaran yang dibutuhkan oleh siswa. Adapun hal-hal yang tercatat sebagai kekurangan buku ini, antara lain dikemukakan berikut ini. (1) Aspek dan indikator yang perlu diberikan kepada siswa tidak merata, bahkan ada aspek dan indikator yang sama sekali tidak ada di dalam buku pelajaran ini. (2) Tugas dan latihan soal juga masih kurang dalam memuat aspek dan indikator tentang ekosistem baik abiotik maupun biotik.

\section{Bahasa Indonesia untuk SMP/MTs Kelas IX Karya Atikah Anindyarini, Yuwono, dan Suhartanto}

Buku ketiga yang dianalisis adalah Bahasa Indonesia untuk SMP/MTs Kelas IX Atikah Anindyarini, Yuwono, dan Suhartanto (selanjutnya disingkat BI9 AAYS) yang diterbitkan oleh Pusat Perbukuan Departemen Pendidikan Nasional pada tahun 2008, dengan tebal buku194 + vii halaman.

Berdasarkan hasil analisis, ditemukan sembilan komponen kecerdasan ekologis dan 23 aspek dari 32 aspek. Apabila ditinjau dari persentase kemunculannya, komponen kecerdasan ekologis telah mencapai $100 \%$; sedangkan persentase kemunculan aspek kecerdasan ekologis $71,87 \%$.

Bagian-bagian kecerdasan ekologis yang dimunculkan dalam buku BI9 AAYS dideskripsikan berikut ini. Muatan mengidentifikasi komponen ekosistem 
abiotik dan biotik. Wacana Pelajaran 1 memuat unsur air dan cahaya. Hal tersebut diulang kembali pada uji kompetensi ("Biji kopi itu dicuci hingga bersih dan dijemur dua-tiga hari agar benar-benar kering."). Sinopsis novel pada Pelajaran 7 menyebutkan beberapa unsur abiotik, yaitu air, sinar matahari, dan sawah (BI9 AAYS, 2008: 3, 15, dan 17).

Aspek biotik dalam buku BI9 AAYS diperkenalkan kepada siswa melalui kutipan "... daun pisang ...." dan "... buah nangka ....". Keduanya merupakan tumbuhan yang masuk pada unsur biotik. Selanjutnya, pada Uji Kompetensi Semester 1 disebutkan unsur biotik berupa hewan (itik) dan pada wacana Pelajaran 7 disebutkan tanaman padi dan melon. Pada wacana lain disebutkan unsur subdimensi biotik berupa hutan mangrove, ikan, kayu, dan kera berhidung panjang dan berbulu kuning emas (BI9 AAYS, 2008: 7, 9, 92, 123, dan 188).

Komponen memahami fungsi dan kegunaan komponen ekosistem aspek abiotik dan biotik. Pada wacana ditemukan kalimat, "Biji kopi itu dicuci hingga bersih dan dijemur dua-tiga hari agar benar-benar kering." Kalimat tersebut memberikan pemahaman kepada siswa bahwa salah satufungsi air adalah untuk mencuci; sedangkan fungsi cahaya untuk menjemur. Pada bacaan Pelajaran 7 siswa diberi pemahaman mengenai fungsi unsur abiotik yang berupa airberfungsi untuk mengairi sawah (BI9 AAYS, 2008: 3 \& 117).

Buku BI9 AAYS menyajikan materi pada salah satu soal Uji Kompetensi Semester 1 berupa sebuah paragraf yang mengandung subdimensi biotik, "Itik Indonesia baik sekali diternakkan. Pemeliharaannya sederhana, telurnya banyak, dan memiliki dayatahan tahan yang baik terhadap penyakit. Ia kuat sekali berjalan jauh" (BI9 AAYS, 2008: 92).

Komponen memahami sistem pengelolaan lingkungan disajikan buku BI9
AAYS berkaitan dengan aspek abiotik saja. Pelajaran 7 memberikan pemahaman terhadap siswa mengenai sistem pengelolaan unsur abiotik (air) secara tepat(BI9 AAYS, 2008: 117).

Komponen memahami tata nilai lingkungan pada buku ini disampaikan berhubungan dengan nilai kearifan lokal dan normatif. Nilai kearifan lokal yang biasanya berhubungan dengan nilainilai pada daerah tertentu, dalam buku pelajaran ini disajikan berkaitan dengan lingkungan biotik.

Uji Kompetensi Pelajaran 7 menyajikan bacaan yang memberikan pemahaman kepada siswa mengenai nilai kearifan lokal di daerah tempat diceritakannya peristiwa (Banjar), "Seorang arsitek pengairan di Banjar baru saja selesai mengubur kepala kerbau untuk mengeringkan rawa Lakbok." Dari penggalan kalimat tersebut siswa dapat memahami bahwa nilai kearifan lokal di daerah Banjar menggunakan kepala kerbau untuk mengeringkan rawa (BI9 AAYS, 2008: 126).

Komponen menunjukkan sikap menghargai lingkungan serta keprihatinan atas kerusakan/pencemaran lingkungan dikemukakan melalui deskripsi subdimensi aspek abiotik dan biotik. Dijelaskan bahwa salah satu wujud keprihatinan yang perlu ditunjukkan oleh siswa adalah sikap prihatin terhadap kerusakan lingkungan abiotik. Buku pelajaran ini memuat bacaan-bacaan yang mendorong siswa untuk menunjukkan sikap keprihatinannya tersebut (BI9 AAYS, 2008:101).

Sinopsis novel Kemarau karya A.A. Navis pada Pelajaran 7 merupakan contoh muatan yang mendorong siswa untuk menunjukkan sikap prihatin terhadap kerusakan unsur abiotik. "Para petani semakin merasa berputus asa karena musim kemarau yang panjang ... Keadaan itu membuat mereka tdak mau lagi mengolah sawah atau mengairi sawah mereka." Sikap yang muncul yaitu keprihatinan terhadap kondisi sawah yang diterlantarkan oleh para petani (BI9 AAYS, 2008:117).

Kecerdasan Ekologis dalam Buku Sekolah Elektronik Mata Pelajaran Bahasa Indonesia SMP 
Komponen melakukan adaptasi tingkah laku terhadap lingkungan abiotik dan abiotik. Setiap manusia diwajibkan untuk bisa beradaptasi dengan lingkungan sekitar. Dengan adaptasi tersebut, manusia dapat dengan mudah berinteraksi dalam kehidupannya. Salah satu adaptasi yang diperlukan adalah adaptasi dengan lingkungan abiotik. Bacaan Pelajaran 7 menunjukkan contoh strategi beradaptasi dengan lingkungan abiotik.

"Suatu hari ada seorang bocah kecil bernama Acin yang membantunya mengairi sawah sehingga keduanya saling bergantian mengambil air di danau dan mengairi sawah ...." (BI9 AAYS, 2008:117).

Siswa mengerti harus bertingkah laku seperti apa untuk menghadapi musim kemarau dengan cuaca yang sangat panas.

Komponen memecahkan masalah yang timbul dari dampak lingkungan dikemukakan dalam beberapa bentuk. Pada wacana Pelajaran 7 siswa secara individual diberi strategi menyikapi permasalahan yang muncul akibat dari lingkungan abiotik. Siswa tetap harus bisa memanfaatkan lahan pertanian meskipun dalam cuaca yang panas (musim kemarau) (BI9 AAYS, 2008:123).

Komponen mengelola/melestarikan sumber lingkungan hidup pada buku ini dikemukakan dalam beberapa unsur. Di dalam buku pelajaran ini disajikan materimateri yang memberikan cara kepada siswa secara individual untuk melestarikan unsur abiotik dan biotik, di antaranya tersaji dalam contoh teks pidato. Dalam teks pidato dimuat strategi untuk melestarikan unsur abiotik, antara lain: (1) Menjaga kebersihan, membuang sampah pada tempatnya sehingga kota terlihat bersih dan (2) Menjaga program kali bersih yang sudah dicanangkan. Tidak membuang sampah ke sungai membuat aliran air lancar, tidak banjir, dan tidak menyebabkan polusi air. Isi pidato juga memberikan cara untuk melestarikan unsur biotik, yakni dengan menjaga ta- man dan memeliharanya, sesekali dengan merawat dan membersihkan taman (BI9 AAYS, 2008: 133).

Komponen memanfaatkan lingkungan secara positif dalam buku ini hanya ditampilkan pada satu aspek, yaitu aspek biotik. Pelajaran 1 memberikan cara kepada siswa untuk bisa memanfaatkan unsur abiotik secara positif. "Biji kopi itu dicuci hingga bersih dan dijemur dua-tiga hari agar benar-benar kering." Dari kalimat tersebut siswa dapat memanfaatkan air untuk mencuci biji kopi dan menjemurnya menggunakan cahaya. Pemanfaatan kedua unsur ini sangat positif karena memberikan keuntungan bagi pengguna (BI9 AAYS, 2008: 3).

Sebagaimana layaknya buku sekolah elektronik yang telah lolos peniaian oleh Badan Standar nasional pendidikan, materi, tugas, dan latihan soalyang terdapat dalam buku ini sudah sesuai dengan kompetensi dasar yang harus dipelajari oleh siswa. Sementara itu ditinjau dari perpektif muatan kecerdasan ekologis, kekurangan yang terdapat dalam buku ini adalah (1) ada sejumlah apek kecerdasan ekologis yang tidak tersaji dan (2) muatan aspek dan indikator tentang ekosistem baik abiotik maupun biotik pada tugas dan latihan/ soal masih kurang.

\section{Bahasa dan Sastra Indonesia 3 untuk SMP/MTs Kelas IX Karya Maryati dan Sutopo}

Buku keempatyang menjadi objek kajian dalam penelitian ini berjudul Bahasa dan Sastra Indonesia 3 untuk SMP/MTs Kelas IX karyaMaryati dan Sutopo (selanjutnya disingkat BSI3 MS) yang diterbitkan oleh Penerbit Erlangga pada tahun 2008 dan memiliki ketebalan sejumlah $\mathrm{x}+228$ halaman.

Berdasarkan hasil analisis yang telah dilakukan, hanya ditemukan tiga dari sembilan komponen kecerdasan ekologis dalam buku pelajaran tersebut, yakni mengidentifikasi komponen ekosistem, 
memahami fungsi dan kegunaan komponen ekosistem, serta memahami sistem pengelolaan lingkungan. Jika ditinjau dari segi komponennya, buku pelajaran ini hanya menampilkan lima dari sembilan kompoen kecerdasab ekologis (55,55\%). Sementara itu,jika ditinjau dari aspeknya, buku ini hanya mengakomodasi delapan dari 32 aspek kecerdasan ekologis yang ada $(25 \%)$.

Hasil analisis tiap komponen dan aspek dapat dipaparkan berikut ini. Muatan kecerdasab ekologis pertama adalah mengidentifikasi komponen ekosistem, baik aspek abiotik maupun biotik disajikan pada buku BSI3 MS. Buku ini banyak memuat unsur abiotik yang harus dikenali oleh siswa, seperti tampak pada kutipan cerita pada Pelajaran 1 berikut, "Matahari semakin hangat melelehkan selapis tipis salju." (BSI3 MS, 2008: 7). Sementara muatan aspk biotik seperti tampak pada kutipan cerita "Anak-anak asrama suka mengganggu. Mengambil tomat. Mengambil ikatan kacang. Bukan untuk dimakan, hanya untuk mengganggu Mang Sayur yang baik hati (BSI3 MS, 2008: 3).

Pemahaman fungsi dan kegunaan ekosistem pada aspek abiotik dan biotik dalam buku BSI3 MS ditampilkan kutipan cerpen berjudul "Emak" yang di dalamnya ditemukan kutipan "Tadi, saat aku cuci nggak ada noda kayak gini." (BSI3 MS, 2008: 69) dan Nabila menyirami bunga tadi sore." (BSI3 MS, 2008: 100). Kutipan tersebut menyebutkan fungsi unsur abiotik air, yaitu untuk mencuci dan menyirami bunga. Sementara itu, usur biotik antara lain terdapat pada bagian Uji Kompetensi buku BSI3 MS, seperti pada kutipan "Jamu Tradional Temu Lawak Akan menyembuhkan keluhan Anda: Nyeri perut, muka pucat, sering pusing,dan berbagai keluhan penyakit lain (BSI3 MS, 2008: 137). Hal itu memberikan pemahaman mengenai fungsi dan kegunaan unsur biotik tanaman temulawak yang bermanfaat menyembuhkan keluhan nyeri perut, muka pucat, sering pusing, dan berbagai keluhan penyakit lain.

Berkenaan dengan pemahaman sistem pengelolaan lingkungan, buku ini hanya menampilkan materi yang berkaitan dengan aspek biotik, seperti tampak pada bagian Uji Kompetensi nomor 11(BSI3 MS, 2008: 141). Dalam kutipan tersebut ditekankan pentingnya pemupukan yang berimbang untuk mendapatkan padi berkualitas.

Buku ini juga memiliki muatan mengenai pemahaman tata nilai lingkungan, baik pada aspek nilai religius maupun normatif. Pada kutipan cerpen terdapat kalimat "Apabila kupandang air muka ayah, aku merasa senang. Mukanya bersih karena berkali-kali dicuci apabila mengambil air sembahyang." Selanjutnya dalam kutipan cerpen ditemukan kalimat "Lestarikan lingkungan kita sebagai wujud syukur kita kepada Sang Maha Pencipta" (BSI3 MS, 2008: 10 \& 94).

Meskipun tidak banyak, buku ini juga mengandung nilai kecderdasan ekologis yang berkenaan dengan menunjukkan sikap positif terhadap lingkungan (keprihatinan dan menghargai) pada aspek biotik yang ditampilkan dalam BSI3 MS tidak begitu banyak. Sebagai contoh dapat kemukakan kutipan puisi berikut ini:

\section{Untuk Kita Renungkan \\ ... \\ Anak menjerit-jerit, asap panas memba- kar \\ Lahar dan badai menyapu bersih Ini bukan hukuman hanya satu isyarat \\ Agar kita mesti banyak berbenah ...}

Ditinjau dari kriteria yang ditetapkan BSNP, buku ini memiliki sejumlah kelebihan sebagai berikut. (21) Setiap bagian pelajaran diawali dengan pengantar yang menunjukkan pentingnya penguasaan kompetensi dasar tertentu bagi siswa. (2) Uji latih kompetensi, uji kebahasaan,

Kecerdasan Ekologis dalam Buku Sekolah Elektronik Mata Pelajaran Bahasa Indonesia SMP 
dan uji kompetensi sudah sesuai dengan kompetensi dasar yang harus dipelajari oleh siswa. (2) Setiap bagian pelajaran dalam buku ini sudah diberi materi pengantar pembelajaran yang dibutuhkan oleh siswa. Sementa itu, kekurangan buku ini, khsusnya jika dilihat dari perpektif muatan kecerdasan ekologis, banyak apek kecerdasan ekologis yang tidak tersaji dan belum mampu memberikan pemahaman yang memadai bagi siswa mengenai pentingnya menjaga dan melestarikan lingkungan.

\section{SIMPULAN}

Berdasarkan hasil penelitian dan pembahasan dapat dikemukakan beberapa simpulan sebagai berikut. Pertama, kecerdasan ekologis adalah kemampuan manusia dalam berinteraksi dengan lingkungan serta kemampuan beradaptasi, mengontrol, mengatur, mempeduli, menjaga, melestarikan, dan memanfaatkan lingkungannya demi kelangsungan hidup manusia. Komponen yang tercakup dalam kecerdasan ekologis meliputi (1) mengidentifikasi komponen-komponen ekosistem; (2) memahami fungsi dan kegunaan komponen ekosistem; (3) memahami sistem pengelolaan alam dan lingkungan; (4) memahami tata nilai lingkungan, yang meliputi nilai kearifan lokal, nilai religius, dan nilai normatif; (5) menunjukkan keprihatinan atas kerusakan lingkungan atau pencemaran lingkungan; (6) melakukan adaptasi tingkah laku terhadap lingkungan; (7) memecahkan masalah yang timbul dari dampak lingkungan; (8) mengelola/melestarikan sumber daya alam; dan (9) memanfaatkan lingkungan secara positif.

Kedua, komponen-komponen kecerdasan ekologis di atas tersaji secara variatif dalam buku pelajaran bahasa Indonesia untuk siswa SMP; dari buku yang hanya memuat tiga komponen kecerdasan ekologis sampai dengan buku yang memuat semua komponen kecer- dasan ekologis. Buku pelajaran bahasa Indonesia untuk SMP pada umumnya masih lebih dominan menyajikan hal-hal yang bersifat pengetahuan dan belum menekankan pada internalisasi nilai kecerdasan ekologis serta penerapannya, baik berupa adaptasi tingkah laku terhadap lingkungan, pemecahan masalah yang timbul dari dampak lingkungan, pengelolaan/pelestarikan sumber daya alam, dan pemanfaatan lingkungan secara positif.

\section{UCAPAN TERIMA KASIH}

Artikel ini merupakan sebagian dari hasil penelitian eksploratif untuk mengembangkan model Buku Teks Bahasa Indonesia Berbasis Kecerdasan Ekologis bagi Siswa SMP. Penelitian ini terlaksana atas bantuan dana dari Direktorat Penelitian Pengabdian kepada MasyarakatDikti melalui Skim Hibah Kompetensi (Hikom) dengan nomor kontrak 339/UN27.11/ PL/2015. Atas kesempatan yang diberikan kami mengucapkan terima kasih. Ucapan terima kasih juga kami sampaikan kepada kepala sekolah dan guru bahasa Indonesia SMP di Surakarta termpat penelitian ini dilaksanakan. Kepada redaksi LITERA terima kasih atas dimuatnya artikel ini.

\section{DAFTAR PUSTAKA}

As-syakur, A.R., dkk. 2010. "Studi Perubahan Penggunaan Lahan di DAS Badung". Dalam Jurnal Bumi Lestari, Vol. 10, No. 2. pp. 200-208.

Capra, Fritjof. 1997. The Web of Life: A New Scientific Understanding of Living Systems. London: Flamingo.

Capra, Fritjof. 2004. The Hidden Connections: A Science for Sustainable Living. London: Flamingo.

Cunningsworth, Alan. 1995. Choosing Your Coursbook. Oxford: Heinemann.

Goleman, Daniel. 2009. Ecological Intellegence: How Knowing the Hidden Impact of What We Buy Can Change Everything, New York: Broadway Books. 
Kasia, Rahmad, dkk. 2011. Penanganan Masalah Pembalakan Liar di Kawasan Ulu Masen, Aceh: Strategi, Aksi dan Tujuan di Masa Yang Datang. Aceh: Laporan Fauna \& Flora International.

Keraf, A. Sonny. 2014. Filsafat Lingkungan Hidup: Alam sebagai Sebuah Sistem Kehidupan Bersama Fritjof Capra. Yogyakarta: Kanisius.

Pilgrim, Sarah E., et.al. 2008. "Ecological Knowledge is Lost in Wealthier Communities and Countries". Environmental Science \& Technology/Vol. 42, No. 4.

Richards, Jack C. 2002. Curriculum Development in Language Teaching. New York: Cambridge University Press.

Riswan, Henna Rya Sunoko, dan Agus Hadiyarto. 2011. “Pengelolaan Sampah Rumah Tangga di Kecamatan Daha Selatan". Jurnal Ilmu Lingkungan Vol.9, No. 1, April 2011.

Santoso, Harry. 2012. "Aplikasi “SSOP BANTAL" Berbasis DAS untuk Penanggulangan Banjir dan Tanah Longsor. Jurnal Penanggulangan Bencana Volume 3 Nomor 1, Tahun 2012.

Sartohadi, Junun dan Suyono. 2003. "Mencermati Penyebab Banjir Pantai Utara Jawa Tengah pada Satuan Wilayah Sungai Pemali-Comal". Prosiding Lokakarya Nasional dengan Tema Menuju Pengelolaan Sumberdaya Wilayah Berbasis Ekosistem untuk Mereduksi Potensi Konflik Antardaerah.
Soemarwoto, Otto. 1991. Ekologi, Lingkungan Hidup, dan Pembangunan. Jakarta: Djambatan.

Suganda, Emirhadi, Yandi Andri Yatmo, dan Paramita Atmodiwirjo. 2009. "Pengelolaan Lingkungan dan Kondisi Masyarakat pada Wilayah Hilir Sungai". Makara, Sosial Humaniora, Vol. 13, No. 2, Desember 2009: 143153.

Turner, Nancy J., Ignace, Marianne Boelscher, and Ignace, Ronald. 2000. "Traditional Ecological Knowledge And Wisdom Of Aboriginal Peoples In British Columbia". Ecological Applicationis, 10 (5), 2000, pp. 12751287, 2000 by the Ecological Society of America.

Utina, Ramli. 2012. “Kecerdasan Ekologis dalam Kearifan Lokal Masyarakat Bajo Desa Torosiaje Provinsi Gorontalo". Makalah. Dimuat dalam Prosiding Konferensi dan Seminar Nasional Pusat Studi Lingkungan Hidup Indonesia Ke 2, 13-15 September 2012 di Mataram.

Wills, Jane. 1996. A Framework for TaskBased Learning. England: Longman.

Widdowson, H.G. 1987. "The Teaching of English as Communication" The Communicative Approach to Language Teaching, (ed) C.J. Brumfit dan K. Johnson. Oxford: Oxford University Press.

http://www.republika.co.id/berita/nasional/umum/14/03/04/n1wxjl-bnpb245-orang-meninggal-akibat-bencana2014 